Łukasz Gawor, Anna SzmatŁoch

Politechnika Śląska, Gliwice, Polska

PiOTR DoLNicki

Uniwersytet Pedagogiczny, Kraków, Polska

\title{
Waloryzacja zwałowisk pogórniczych jako obiektów geoturystycznych na przykładzie Zagłębia Ruhry
}

\section{Valorization of Post-mining Dumping Grounds as Geotourism Sites on the Example of the Ruhr Region}

Streszczenie: Zwałowiska pogórnicze stanowią nieodłączny element krajobrazu każdego z większych miast Zagłębia Ruhry oraz Górnośląskiego Zagłębia Węglowego (GZW). Rekultywacja tych form terenu stanowi ważny element zagospodarowania przestrzennego dla tych obszarów. Istnieje wiele metod wyznaczania poziomu rekultywacji oraz przystosowania tych form do celów funkcjonalnych. Autorzy podjęli próbę oceny zwałowisk w Zagłębiu Ruhry. W niniejszej pracy wykorzystano metodę waloryzacji zwałowisk i przeprowadzono analizę, wykorzystując koncepcję zasad waloryzacji dla zwałowisk węgla kamiennego zlokalizowanych na terenie Górnośląskiego Zagłębia Węglowego. Koncepcja ta zawiera ocenę w oparciu o dwa kryteria: wartość merytoryczną oraz dostępność. Do badań wytypowano dwadzieścia reprezentatywnych obiektów, kierując się powierzchnią zwałowisk, lokalizacją, zagospodarowaniem oraz złożonością problemów środowiskowych. Uzyskane wyniki wysoko oceniają zwałowiska zlokalizowane w Zagłębiu Ruhry, co stanowi o wysokim stopniu rekultywacji. Próba waloryzacji zwałowisk po górnictwie węgla kamiennego zlokalizowanych w Zagłębiu Ruhry, przy wykorzystaniu zasad waloryzacji stworzonych dla zwałowisk zlokalizowanych w GZW, wykazała, iż konieczne były pewne modyfikacje tych zasad. Dotyczyły one głównie zagospodarowania i położenia zarówno samych zwałowisk, jak i ogólnego zagospodarowania terenu (m.in. turystycznego). Analizując wyniki waloryzacji, da się zauważyć istotność efektywnej rekultywacji zwałowisk, wynikającej ze szczegółowych uregulowań prawnych. Nie bez znaczenia jest również fakt, iż antropogeniczne formy terenu, takie jak zwałowiska pogórnicze, są wykorzystywane do celów dydaktycznych, rekreacyjnych czy krajobrazowych.

Abstract: Post-mining dumping grounds are inseparably connected with the landscape of every larger city of the Ruhr Region and Upper Silesian Coal Basin. The restoration of these landforms belongs to the most important elements of spatial planning in these areas. There are different methods of assigning a level of restoration and adapting the above mentioned landforms for functional purposes. The authors tried to evaluate dumping grounds in the Ruhr Region. 
In the paper, a method of valorization of dumping grounds is used, and an analysis using the concept of valorization for dumping grounds from coal mining industry situated in Upper Silesian Coal Basin is done. This concept includes an evaluation based on two criteria: substantial value and accessibility. Twenty representative objects were analyzed according to their surface, location, land utilization and complexity of environmental problems.

The obtained results allow rating the dumping grounds situated in the Ruhr Region highly, which is connected with the high level of restoration. An attempt of valorization of post mining dumping grounds situated in the Ruhr Region using the rules of valorization elaborated in Upper Silesian Coal Basin showed that there were necessary some modifications in these rules. They were related mainly to the way of using and location of the dumping grounds as well as general land utilization (e.g. in a touristic way). The analysis of the results of valorization shows the importance of effective restoration of the dumps, resulting from particular legal regulations. There is also one important fact that anthropogenic landforms like post mining dumping grounds are used for didactic, recreation and landscape purposes.

Słowa kluczowe: waloryzacja i zagospodarowanie zwałowisk; zwałowiska pogórnicze

Key words: post mining dumping grounds, valorization and land utilization of dumping grounds

\section{WSTĘP}

Zwałowiska pogórnicze Zagłębia Ruhry cechują się zaawansowanym stopniem rekultywacji oraz interesującymi formami zagospodarowania. W porównaniu ze zwałowiskami polskimi obiekty niemieckie mogą stanowić przykład efektywnej rekultywacji, która wynika ze szczegółowych uregulowań prawnych. Zwałowiska Zagłębia Ruhry pełnią w regionie rolę krajobrazową, rekreacyjną oraz geoturystyczną (czyli mogą być traktowane jako obiekty geoturystyczne). Zgodnie z niepublikowaną definicją prof. Krystiana Probierza, geoturystyka jest wielowymiarową formą działalności człowieka zajmującą się opisem, dokumentowaniem, prezentowaniem i propagowaniem walorów estetyczno-kulturowych i dydaktycznych oraz taką organizacją poznawania obiektów przyrody nieożywionej i zabytków techniki, która umożliwia ich zwiedzanie i użytkowanie dla celów rekreacyjno-turystycznych, pozwalając na aktywne ,zagospodarowanie” czasu wolnego. Pojmowana może być także jako jeden z rodzajów turystyki kwalifikowanej i podobnie jak inne rodzaje turystyki, ze względu na swoją złożoność, jest przedmiotem wszechstronnych badań, stanowiąc oczywiście również efektowną i efektywną formę działalności gospodarczej. Zwałowiska pogórnicze mogą być traktowane jako obiekty geologiczne (są zbudowane ze skały płonnej) i geomorfologiczne (antropogeniczne formy terenu), należą zatem do obiektów przyrody nieożywionej i mogą być uznane za obiekty geoturystyczne.

Dotychczas dla zwałowisk polskich stworzone zostały kryteria waloryzacji (Gawor, Szmatłoch, 2010), które po modyfikacji zastosowano do zwałowisk Zagłębia Ruhry. Problem waloryzacji zwałowisk pogórniczych jest istotny z praktycznego punktu widzenia, pozwala bowiem porównać podobne problemy rekultywacji i zagospodarowania tych obiektów w odmiennych warunkach transformacji sektora górniczego w Niemczech i w Polsce. W przyszłości cenne będzie porównanie wyników waloryzacji dla obiektów polskich 
i niemieckich w celu wykorzystania doświadczeń dotyczących rekultywacji i zagospodarowania w Zagłębiu Ruhry na obszarze Górnośląskiego Zagłębia Węglowego (GZW).

\section{CharakterystyKa ZWAŁOWISK POGÓRNICZYCH ZAGŁĘBIA Ruhry}

Charakterystykę zwałowisk pogórniczych w badanych obszarach przeprowadzono na podstawie literatury, materiałów kartograficznych oraz danych udostępnionych przez Bezirksregierung Arnsberg (odpowiednik polskiego Wyższego Urzędu Górniczego) w Dortmundzie. Część informacji zweryfikowano podczas badań terenowych.

Zwałowiska związane z górnictwem węglowym w Zagłębiu Ruhry stanowią nieodłączny składnik krajobrazu przemysłowego każdego z większych miast regionu. Obecnie wskutek likwidacji większości kopalń Zagłębia Ruhry rozwój zwałowisk został zahamowany i funkcjonuje ich jedynie $7 \mathrm{w}$ powiązaniu z działalnością 4 kopalń. Dla porównania na początku lat 80 . czynne były 22 zwałowiska, zaś ogółem na obszarze Zagłębia Ruhry zinwentaryzowano 170 zwałowisk po górnictwie węgla kamiennego (Gawor, 2004; Gawor, Main, 2007).

Zwałowiska środkowej części Zagłębia Ruhry zajmują powierzchnię ok. 1550 ha (0,82\% w odniesieniu do terenu o powierzchni $1880 \mathrm{~km}^{2}$ ). Większość zwałowisk ma kształt regularny, zbliżony do kolistego, rzadziej wydłużony, o przeważającej orientacji N-S. Największe zwałowisko ma powierzchnię ok. 200 ha (zwałowiska dawnej kopalni Minister Aschenbach w Dortmundzie), najmniejsze ok. 6 ha (zwałowiska dawnej kopalni Pluto w Gelsenkirchen), średnia powierzchnia jednego zwałowiska wynosi 47 ha. Maksymalna wysokość względna zwałowisk wynosi $150 \mathrm{~m}$ (zwałowisko Grosses Holz), największe pod względem powierzchni zwałowiska osiągają wysokość względną ok. 100 m (zwałowisko Knappen 100 m, zwałowisko Prosper - 90 m). W tabeli 1 przedstawiono czynne zwałowiska w Zagłębiu Ruhry (Gawor, 2004; Gawor, Main, 2007).

Tab. 1. Czynne zwałowiska w Zagłębiu Ruhry

\begin{tabular}{|l|l|l|c|c|c|}
\hline \multicolumn{1}{|c|}{ Nazwa } & \multicolumn{1}{|c|}{ Położenie } & \multicolumn{1}{c|}{ Kopalnia } & Rok zał. & $\begin{array}{c}\text { Pow. } \\
(\text { ha })\end{array}$ & $\begin{array}{c}\text { Obj. } \\
\left(\mathrm{mln} \mathrm{m}^{3}\right)\end{array}$ \\
\hline Rossenray & Kamp-Lintfort & Bergwerg West & 1970 & 38,4 & 2,6 \\
\hline Kohlenhuck & Moers & Bergwerg West & 1984 & 88,8 & 6,0 \\
\hline Franz Haniel & $\begin{array}{l}\text { Bottrop/ } \\
\text { Oberhausen }\end{array}$ & Prosper-Haniel & 1963 & 108,4 & 51,6 \\
\hline Schöttelheide & Bottrop & Prosper-Haniel & 1999 & 66,7 & 1,4 \\
\hline Brinkfortsheide & Marl & Auguste Victoria & 1952 & 124,0 & 38,5 \\
\hline Hopfstener Str. & Hopsten & Ibbenbüren & 1985 & 85,9 & 12,3 \\
\hline $\begin{array}{l}\text { Rudolfschacht } \\
\text { Erw. }\end{array}$ & Ibbenbüren & Ibbenbüren & 1996 & 56,3 & 2,6 \\
\hline
\end{tabular}

Źrodło: opracowanie własne wg danych Bezirksregierung Arnsberg 
Poza wymienionymi zwałowiskami, DSK (Deutsche Steinkohle) nadzoruje jeszcze 26 zwałowisk, które zostały zamknięte w ostatnim czasie lub zostały wyłączone spod nadzoru DSK.

Zwałowiska niemieckie w większości są zrekultywowane i zagospodarowane. W regionie Zagłębia Ruhry stworzono „Trasę kultury przemysłowej” (Route Industriekultur), obejmującą poza zabytkami techniki również antropogeniczne formy terenu, jakimi są zwałowiska pogórnicze. Obiekty te tworzą najczęściej punkty widokowe, ale również są wykorzystywane w celach sportowo-rekreacyjnych (ścieżki rowerowe, konne, tory narciarskie) oraz kulturowo-artystycznych (przedstawienia, wystawy, instalacje artystyczne). Do najbardziej spektakularnych sposobów zagospodarowania zwałowisk Zagłębia Ruhry należy m.in. sztuczny tor narciarski Alpincenter w Bottrop, elektrownia wiatrowa i instalacje artystyczne dotyczące energetyki alternatywnej na zwałowisku Hoppenbruch, zegar słoneczny na zwałowisku Schwerin czy punkt startowy dla sportów powietrznych na zwałowisku Norddeutschland (Held, Schmitt, 2001; Schulz, 2004; Wiggering, Kerth, 1991) (ryc. 1).

Poniżej przedstawiono wspomniane przykłady zagospodarowania zwałowisk w Zagłębiu Ruhry.

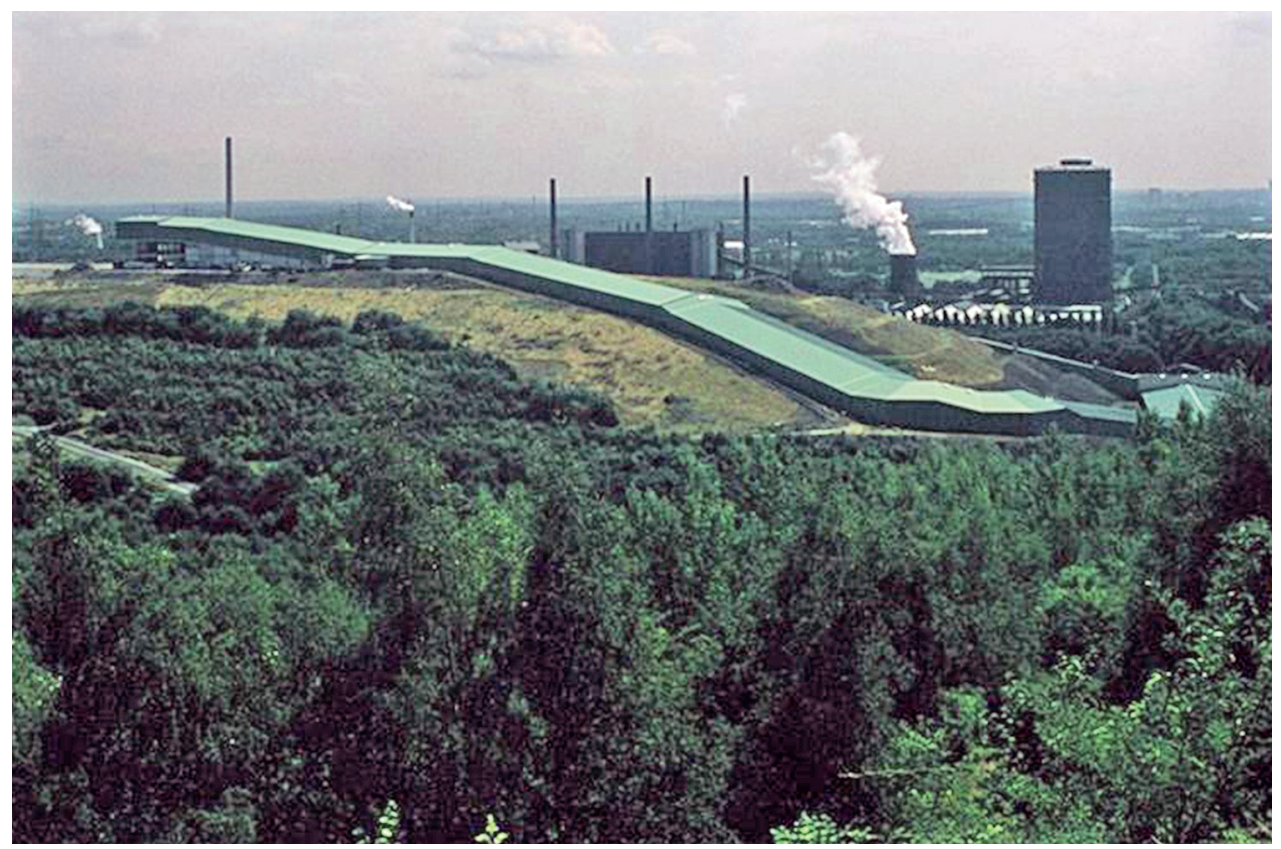

Ryc. 1. Sztuczny tor narciarski Alpincenter na zwałowisku w Bottrop (fot. Ł. Gawor) 


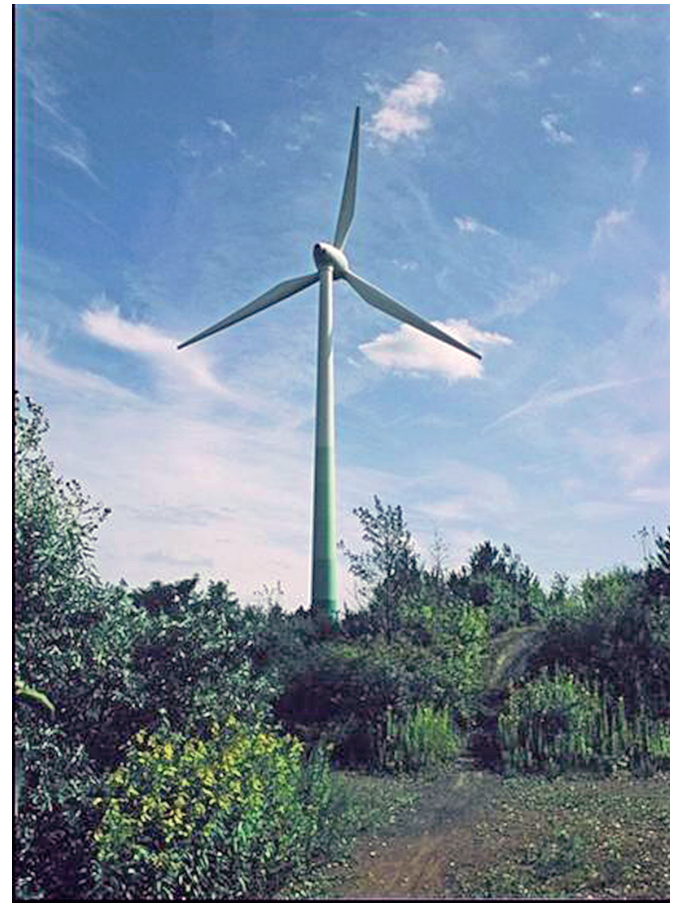

Ryc. 2. Elektrownia wiatrowa na zwałowisku Hoppenbruch w Herten (fot. Ł. Gawor)

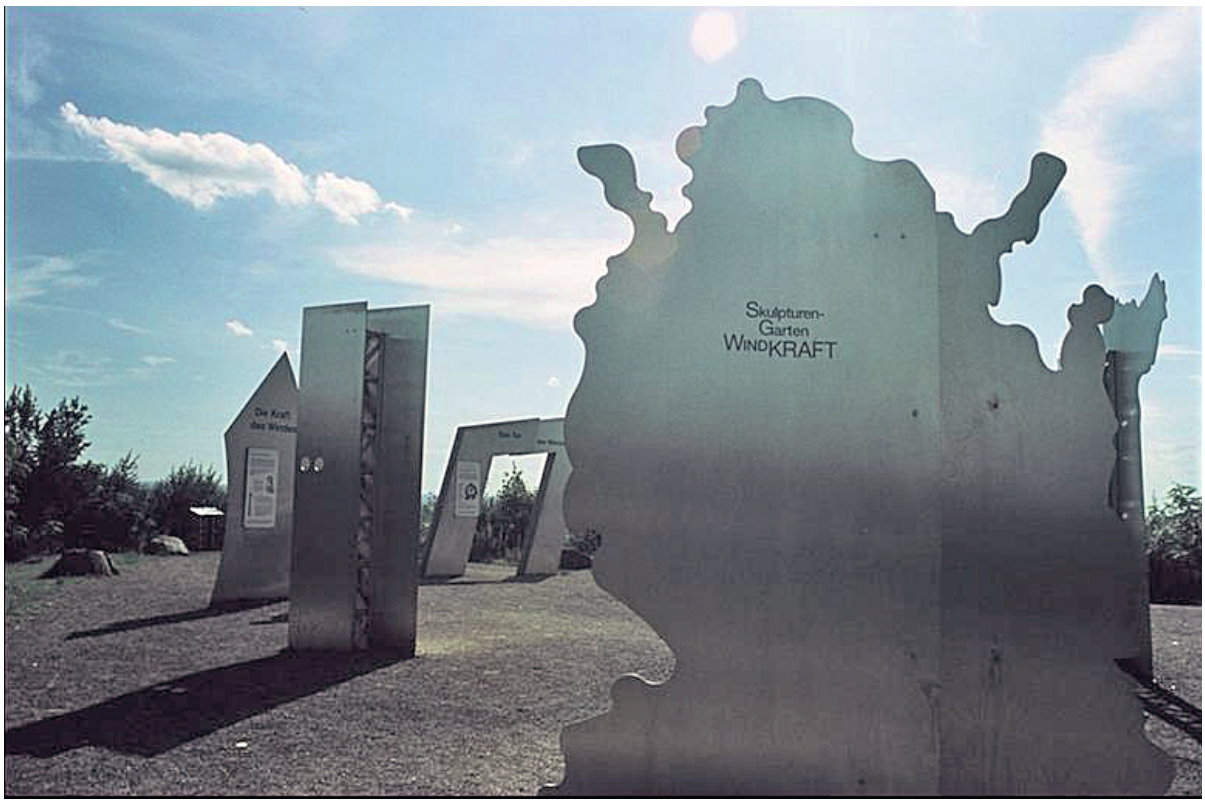

Ryc. 3. Instalacje artystyczne na zwałowisku Hoppenbruch w Herten (fot. Ł. Gawor) 


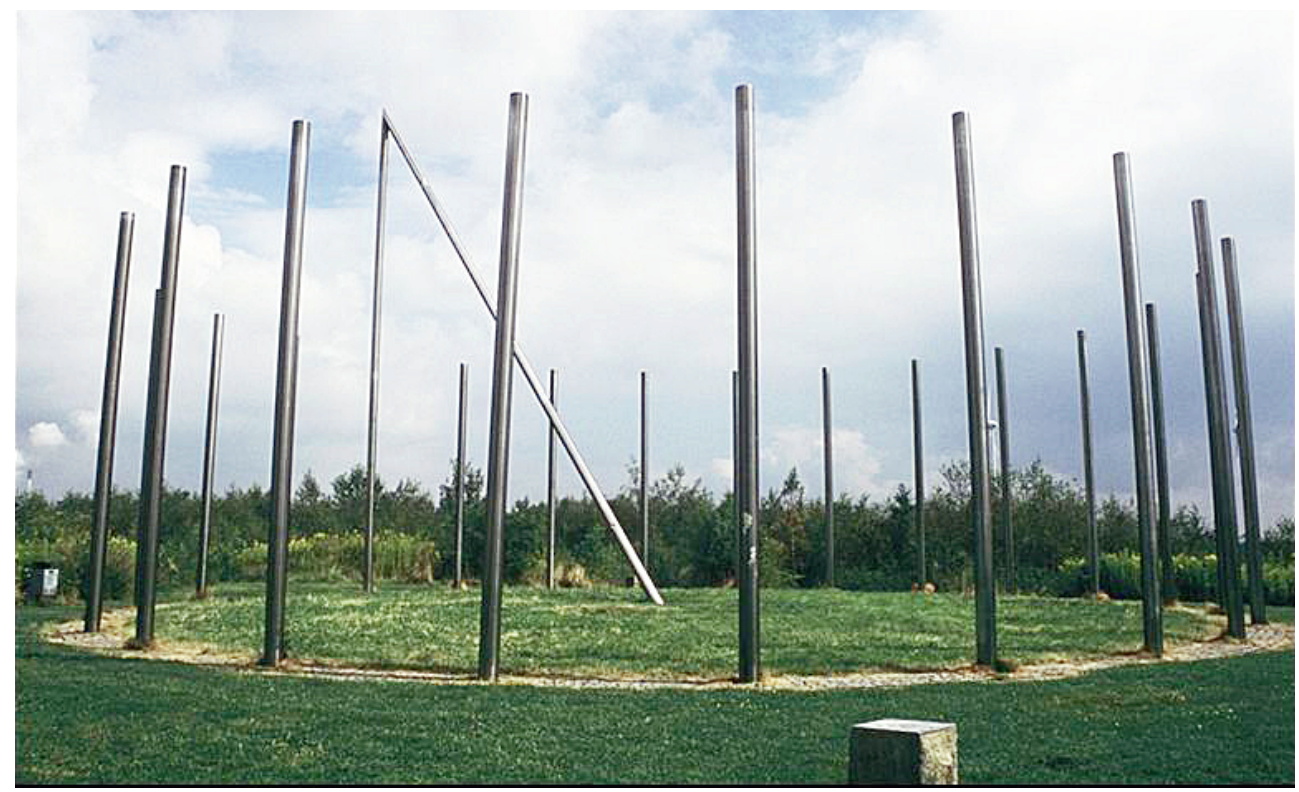

Ryc. 4. Zwałowisko Schwerin - konstrukcja zegara słonecznego (fot. Ł. Gawor)

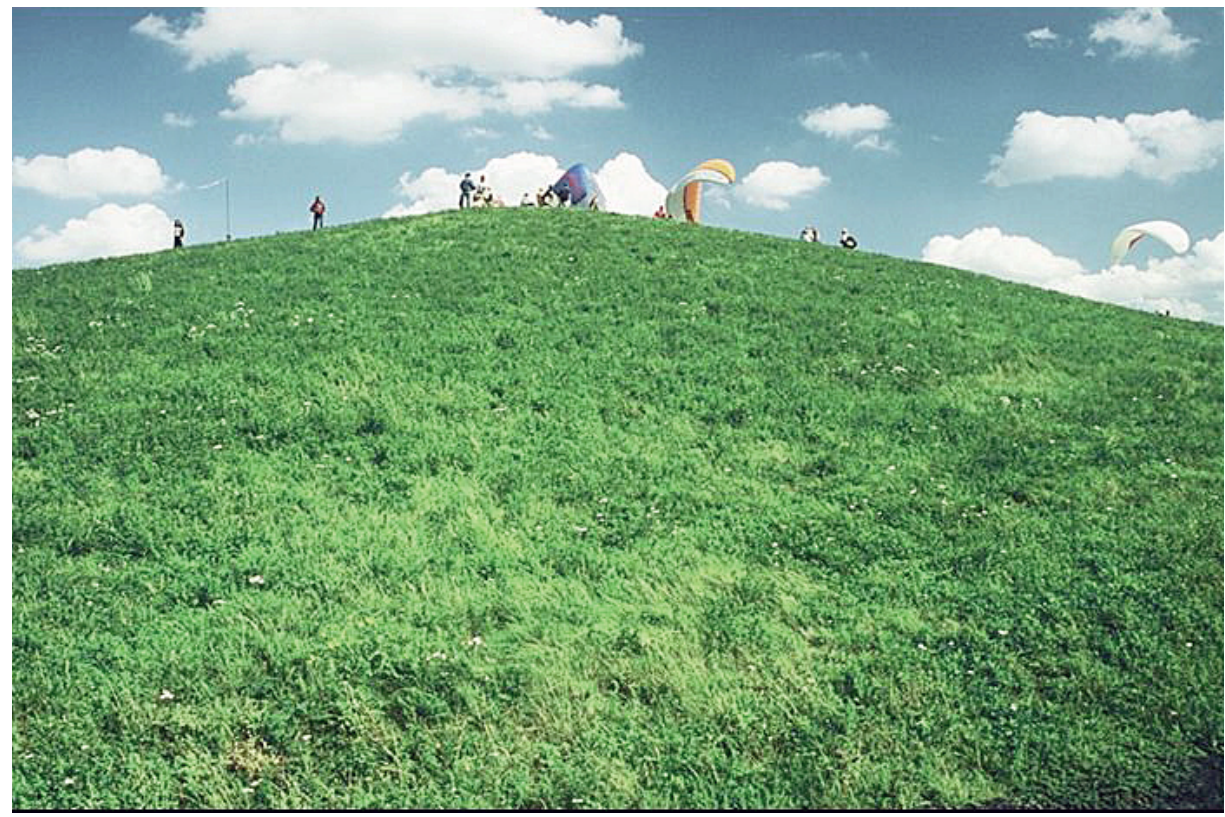

Ryc. 5. Zwałowisko Norddeutschland - punkt startowy dla sportów powietrznych (fot. Ł. Gawor) 


\section{MetodyKa BADAŃ}

Waloryzację zwałowisk przeprowadzono, wykorzystując koncepcję zasad waloryzacji dla zwałowisk węgla kamiennego zlokalizowanych na terenie GZW (Gawor, Szmatłoch, 2010). Koncepcja ta zawiera ocenę w oparciu o dwa kryteria: wartość merytoryczną oraz dostępność. Zaczerpnięto z niej również tok postępowania. Do badań wytypowano dwadzieścia reprezentatywnych obiektów (tab. 2), kierując się powierzchnią zwałowisk, lokalizacją, zagospodarowaniem oraz złożonością problemów środowiskowych.

Tab. 2. Wytypowane zwałowiska niemieckie

\begin{tabular}{|l|l|c|}
\hline \multicolumn{1}{|c|}{ Nazwa } & \multicolumn{1}{|c|}{ Lokalizacja } & Powierzchnia (ha) \\
\hline Prosper/Beckstrasse & Bottrop & 33 \\
\hline Prosperstrasse & Bottrop & 31,5 \\
\hline Schöttelheide & Bottrop & 66,7 \\
\hline Haniel & Bottrop & 106 \\
\hline Grosses Holz & Bergkamen & 140 \\
\hline Hoheward & Herten & 159 \\
\hline Hoppenbruch & Herten & 77,9 \\
\hline Graf Moltke & Gladbeck & 22,8 \\
\hline Mottbruch & Gladbeck & 54,3 \\
\hline Brinkfortsheide & Marl & 124 \\
\hline Rheinelbe & Gelsenkirchen & 18,5 \\
\hline Rungenberg & Gelsenkirchen & 55,3 \\
\hline Oberscholven & Gelsenkirchen-Scholven & 35,8 \\
\hline Norddeutschland & Neukirchen-Vluyn & 81,1 \\
\hline Pattberg & Moers & 48,2 \\
\hline Rheinpreussen & Moers & 45,4 \\
\hline Schwerin & Castrop-Rauxel & 15,8 \\
\hline Schurenbach & Essen & 46,2 \\
\hline Halde Zollverein $1 / 2$ & Essen & 3,8 \\
\hline Brockenscheidt & Waltrop & 6,5 \\
\hline & & \\
\hline
\end{tabular}

Źródło: opracowanie własne

Następnie przeanalizowano statystycznie występowanie sześciu cech w badanych obiektach (tab. 3). Cechy te są składowymi wartości merytorycznej:

Nr 1 - Rekultywacja biologiczna $\left(\mathrm{R}_{\mathrm{B}}\right)$

$\mathrm{Nr} 2$ - Rekultywacja z różnym stopniem uwzględnienia rewaloryzacji krajobrazu $\left(\mathrm{R}_{\mathrm{K}}\right)$

Nr 3 - Frekwencja (F)

$\mathrm{Nr} 4$ - Reprezentatywność $\left(\mathrm{R}_{\mathrm{Z}}\right)$

Nr 5 - Znaczenie regionalne $\left(\mathrm{R}_{\mathrm{G}}\right)$

Nr 6 - Zagospodarowanie (Z) 
Tab. 3. Zestawienie występowania najważniejszych cech w wybranych dwudziestu obiektach

\begin{tabular}{|c|c|c|c|c|c|c|}
\hline \multirow{2}{*}{ Obiekt } & \multicolumn{6}{|c|}{ Cecha } \\
\hline & $\mathrm{R}_{\mathrm{B}}$ & $\mathrm{R}_{\mathrm{K}}$ & $\mathrm{F}$ & $\mathrm{R}_{\mathrm{Z}}$ & $\mathrm{R}_{\mathrm{G}}$ & $\mathrm{Z}$ \\
\hline $\mathrm{Nr} 1$ & + & + & + & + & + & + \\
\hline $\mathrm{Nr} 2$ & + & + & + & + & + & + \\
\hline $\mathrm{Nr} 3$ & - & + & + & - & - & - \\
\hline $\mathrm{Nr} 4$ & + & + & + & + & - & + \\
\hline $\mathrm{Nr} 5$ & + & + & - & + & - & + \\
\hline $\mathrm{Nr} 6$ & + & + & + & + & + & + \\
\hline $\mathrm{Nr} 7$ & + & + & + & + & - & - \\
\hline $\mathrm{Nr} 8$ & + & + & + & - & - & - \\
\hline $\mathrm{Nr} 9$ & + & + & + & - & - & - \\
\hline $\mathrm{Nr} 10$ & - & + & + & - & - & - \\
\hline $\mathrm{Nr} 11$ & + & + & - & + & + & + \\
\hline Nr 12 & + & + & + & + & + & + \\
\hline Nr 13 & + & - & + & - & - & - \\
\hline $\mathrm{Nr} 14$ & + & + & - & - & - & + \\
\hline $\mathrm{Nr} 15$ & + & + & - & - & - & + \\
\hline $\mathrm{Nr} 16$ & + & + & - & + & - & + \\
\hline $\mathrm{Nr} 17$ & + & + & - & + & - & + \\
\hline $\mathrm{Nr} 18$ & + & + & - & - & + & + \\
\hline Nr 19 & + & + & + & - & - & - \\
\hline $\mathrm{Nr} 20$ & + & + & - & + & + & + \\
\hline
\end{tabular}

Źródło: opracowanie własne

Tab. 4. Zestawienie częstości (w \%) występowania poszczególnych cech w badanych obiektach

\begin{tabular}{|l|c|c|}
\hline \multicolumn{1}{|c|}{ Cecha } & $\begin{array}{c}\text { Występowanie cechy } \\
\text { w badanych obiektach ,+” (\%) }\end{array}$ & Brak cechy,,-” (\%) \\
\hline Nr 1 - Rekultywacja biologiczna & 90 & 10 \\
\hline $\begin{array}{l}\text { Nr 2 - Rekultywacja z różnym stopniem } \\
\text { uwzględnienia rewaloryzacji krajobrazu }\end{array}$ & 95 & 5 \\
\hline Nr 3 - Frekwencja & 60 & 40 \\
\hline Nr 4 - Znaczenie regionalne & 55 & 45 \\
\hline Nr 5 - Reprezentatywność & 35 & 65 \\
\hline Nr 6 - Zagospodarowanie & 70 & 30 \\
\hline
\end{tabular}

Źródło: opracowanie własne

Zestawienie częstości występowania poszczególnych cech (tab. 4) wskazuje pierwsze różnice pomiędzy zwałowiskami zlokalizowanymi na terenie GZW a badanymi obiektami, 
dlatego zaproponowano zmianę w istotności poszczególnych cech. Cechy, których częstość występowania przekroczyła $60 \%$, uznane zostały za cechy główne - należą do nich cechy $\mathrm{nr} 1,2,6$. Pozostałe cechy są traktowane jako uzupełniające. W efekcie zaproponowano inny sposób rangowania dla „Zagospodarowania” oraz „Frekwencji”.

Kolejnym krokiem była analiza dostępności, więc drugie kryterium oceniające zwałowiska również uległo pewnym modyfikacjom.

Analogicznie w stosunku do zwałowisk GZW ocena wartości merytorycznej oraz dostępności mierzona jest według wyznaczonego wzoru. Wartość poszczególnych cech szacowana jest zgodnie z nadanymi rangami w trzystopniowej skali. Rangi te przyjmują wartości: 4 - ranga wysoka, 2 - ranga średnia, 1 - ranga niska. Natomiast w przypadku kryteriów uzupełniających przyjmują rangę 2 lub 1 (Gawor, Szmatłoch, 2010).

\section{ZASADY WALORYZACJI}

\section{Wartość merytoryczna}

Wartość merytoryczna analizowanych obiektów mierzona jest według wzoru:

$$
W_{M}=\log _{2}\left(R_{B} * R_{K} * Z * U\right)[5]
$$

gdzie: $R_{B}$ - Rekultywacja biologiczna, $R_{K}$ - Rekultywacja z różnym stopniem uwzględnienia rewaloryzacji krajobrazu, $F$ - Frekwencja, $U$ - Kryteria uzupełniające $\left(R_{G} * R_{Z} * F\right)$.

Tak obliczana wartość merytoryczna oceniana jest wg następującej skali:

$0 \leq \mathrm{W}_{\mathrm{M}} \leq 3-$ niska wartość merytoryczna;

$4 \leq \mathrm{W}_{\mathrm{M}} \leq 6-$ średnia wartość merytoryczna;

$7 \leq \mathrm{W}_{\mathrm{M}} \leq 9$ - wysoka wartość merytoryczna (Labus, 2005).

Ocenę poszczególnych kryteriów wyznaczać będą odpowiednie rangi nadane obiektom o wartościach 4 (wysoka), 2 (średnia) lub 1 (niska).

Zarówno rekultywacja biologiczna, jak i rekultywacja z różnym stopniem uwzględnienia rewaloryzacji krajobrazu są oceniane analogicznie do zwałowisk GZW i przedstawiają się następująco:

- Rekultywacja biologiczna $\left(\mathrm{R}_{\mathrm{B}}\right)$ :

4 - ranga wysoka - kierunek ogólnoprzyrodniczy, związany z zagospodarowaniem parkowo-rekreacyjnym,

2 - ranga średnia - zadrzewienie o charakterze parkowym,

1 - ranga niska - brak działań rekultywacyjnych, sukcesja naturalna.

- Rekultywacja z różnym stopniem uwzględnienia rewaloryzacji krajobrazu $\left(\mathrm{R}_{\mathrm{K}}\right)$ jako czynnik zważający na kierunek rekultywacji właściwy dla architektury krajobrazu:

4 - ranga wysoka - kierunek ,architektoniczno-krajobrazowy”,

2 - ranga średnia - kierunek ,techniczno-przyrodniczy”,

1 - ranga niska - kierunek ,techniczny”. 
- Zagospodarowanie (Z) - omawiane obiekty w porównaniu do zwałowisk zlokalizowanych na terenie GZW są przykładem wielu możliwości zagospodarowania, co przyczyniło się do zakwalifikowania tej cechy jako kryterium głównego. Ponieważ jest to składowa wartości merytorycznej, najistotniejsze wydaje się zagospodarowanie w kierunku dydaktycznym (ranga wysoka o wartości 4). Taki rodzaj zagospodarowania podkreśla genezę obiektu oraz jego pierwotne przeznaczenie. Średnią rangę (wartość 2) otrzymają zwałowiska zagospodarowane w kierunku sportowo-rekreacyjnym oraz artystycznym, gdyż wykorzystany jest tutaj jedynie sam obiekt. Zwałowiska niezagospodarowane przyjmują rangę o wartości 1.

- Kryteria uzupełniające - składają się z trzech czynników. Znaczenie regionalne $\left(\mathrm{R}_{\mathrm{G}}\right)$, przy którym kluczowy jest element tradycji regionu, oraz reprezentatywność $\left(R_{z}\right)$, która wynika z cech charakterystycznych danego obiektu, nie ulegają zmianie w stosunku do zwałowisk GZW. Przyjmuje się rangę o wartości 2, kiedy kryterium dotyczy badanego obiektu, bądź 1, gdy kryterium nie występuje. Modyfikacji ulega jedynie Frekwencja (F), gdyż zdegradowano ją do kryterium uzupełniającego po zmianie istotności cech występowania w badanych obiektach. Lokalizacja w bliskim sąsiedztwie (do $1 \mathrm{~km}$ ) podobnych obiektów (więcej niż jeden) z zakresu tej samej dziedziny kwalifikuje obiekt do uzyskania rangi o wartości 2. Rangę o wartości 1 uzyska obiekt zlokalizowany przy zakładzie wydobywczym.

\section{Dostępność}

Dostępność, określana ogólnoużytkowo, nie odbiega znacząco od pierwowzoru. Dokonano jedynie zmian kosmetycznych wynikających z różnic w sieci szlaków komunikacyjnych oraz turystycznych. W efekcie rangowanie kryteriów oceniających dostępność przedstawia się następująco:

- Położenie obiektu względem różnego rodzaju szlaków komunikacyjnych:

4 - ranga wysoka - obiekt zlokalizowany przy autostradzie,

2 - ranga średnia - obiekt zlokalizowany przy drodze głównej (odpowiednik drogi krajowej),

1 - ranga niska - obiekt zlokalizowany przy drodze lokalnej (odpowiednik drogi wojewódzkiej lub gminnej).

- Położenie względem szlaków turystycznych:

4 - ranga wysoka - obiekt położony na szlaku tematycznym z danej dziedziny (np.) lub turystycznym,

2 - ranga średnia - obiekt położony na szlaku rowerowym,

1 - ranga niska - obiekt położony poza szlakiem tematycznym z danej dziedziny, turystycznym bądź rowerowym.

- Stopień trudności terenowych:

4 - ranga wysoka - obiekt dobrze wyeksponowany w terenie, brak zagrożeń środowiskowych, dobrze rozwinięta sieć dróg i ścieżek, 
2 - ranga średnia - obiekt słabo wyeksponowany w terenie, brak zagrożeń środowiskowych, słabo rozwinięta sieć dróg i ścieżek,

1 - ranga niska - obiekt położony na terenie prywatnym, ogrodzony, zwiedzanie wymaga zezwolenia lub obiekt o wysokim zagrożeniu środowiskowym.

Dostępność badanych obiektów mierzona jest jako:

$D=\log _{2}\left(P_{K} * P_{T} * S\right)[5]$

gdzie: $P_{K}$ - położenie obiektu względem różnego rodzaju szlaków komunikacyjnych, $P_{T}$ - położenie względem szlaków turystycznych, $S$ - stopień trudności terenowych.

W efekcie dostępność oceniana jest wg następującej skali:

$0 \leq \mathrm{D} \leq 2$ - słaba dostępność; $3 \leq \mathrm{D} \leq 4$ - średnia dostępność; $5 \leq \mathrm{D} \leq 6$ - dobra dostępność.

Tab. 5. Wartość dydaktyczna

\begin{tabular}{|c|c|c|c|c|c|c|c|c|c|c|c|}
\hline \multirow{2}{*}{ Obiekt } & \multicolumn{7}{|c|}{ Wartość merytoryczna } & \multicolumn{4}{|c|}{ Dostępność } \\
\hline & $\mathrm{R}_{\mathrm{B}}$ & $\mathrm{R}_{\mathrm{K}}$ & $\mathrm{Z}$ & $\mathrm{R}_{\mathrm{G}}$ & $\mathrm{R}_{\mathrm{z}}$ & $\mathrm{F}$ & Wynik & $\mathrm{P}_{\mathrm{K}}$ & $\mathrm{P}_{\mathrm{T}}$ & $\mathrm{S}$ & Wynik \\
\hline $\mathrm{Nr} 1$ & 4 & 4 & 2 & 2 & 2 & 2 & wysoka & 4 & 4 & 4 & dobra \\
\hline $\mathrm{Nr} 2$ & 4 & 4 & 2 & 2 & 2 & 2 & wysoka & 4 & 4 & 4 & dobra \\
\hline Nr 3 & 1 & 2 & 1 & 1 & 1 & 2 & niska & 4 & 2 & 2 & średnia \\
\hline $\mathrm{Nr} 4$ & 4 & 4 & 2 & 1 & 2 & 2 & wysoka & 4 & 4 & 4 & dobra \\
\hline $\operatorname{Nr} 5$ & 4 & 4 & 4 & 1 & 2 & 1 & wysoka & 2 & 4 & 4 & dobra \\
\hline $\mathrm{Nr} 6$ & 4 & 4 & 4 & 2 & 2 & 2 & wysoka & 4 & 4 & 4 & dobra \\
\hline $\mathrm{Nr} 7$ & 4 & 4 & 4 & 1 & 2 & 2 & wysoka & 4 & 4 & 4 & dobra \\
\hline $\mathrm{Nr} 8$ & 2 & 4 & 1 & 1 & 1 & 2 & średnia & 1 & 1 & 1 & słaba \\
\hline $\mathrm{Nr} 9$ & 4 & 4 & 1 & 1 & 1 & 2 & średnia & 1 & 1 & 2 & słaba \\
\hline $\mathrm{Nr} 10$ & 1 & 2 & 1 & 1 & 2 & 1 & niska & 2 & 1 & 2 & słaba \\
\hline $\mathrm{Nr} 11$ & 4 & 4 & 2 & 2 & 2 & 1 & wysoka & 1 & 4 & 2 & średnia \\
\hline $\mathrm{Nr} 12$ & 4 & 4 & 2 & 2 & 2 & 1 & wysoka & 4 & 4 & 4 & dobra \\
\hline $\mathrm{Nr} 13$ & 2 & 1 & 1 & 1 & 1 & 1 & niska & 2 & 1 & 2 & słaba \\
\hline $\mathrm{Nr} 14$ & 4 & 4 & 2 & 1 & 1 & 1 & średnia & 2 & 4 & 4 & dobra \\
\hline $\mathrm{Nr} 15$ & 4 & 4 & 2 & 1 & 1 & 1 & średnia & 2 & 4 & 4 & dobra \\
\hline $\mathrm{Nr} 16$ & 4 & 4 & 2 & 1 & 2 & 1 & średnia & 2 & 4 & 4 & dobra \\
\hline $\mathrm{Nr} 17$ & 4 & 4 & 4 & 1 & 2 & 1 & wysoka & 2 & 4 & 4 & dobra \\
\hline $\mathrm{Nr} 18$ & 2 & 4 & 2 & 2 & 1 & 1 & średnia & 4 & 4 & 4 & dobra \\
\hline $\mathrm{Nr} 19$ & 4 & 4 & 1 & 1 & 1 & 2 & średnia & 2 & 4 & 2 & średnia \\
\hline $\mathrm{Nr} 20$ & 4 & 4 & 2 & 2 & 2 & 1 & wysoka & 2 & 4 & 4 & dobra \\
\hline
\end{tabular}

Źródło: opracowanie własne 
Podsumowanie

Wyniki waloryzacji kształtowały się następująco: 10 analizowanych obiektów otrzymało wysoką wartość merytoryczną, 7 - wartość średnią i jedynie 3 obiekty zostały ocenione najniżej. Znaczna liczba obiektów zakwalifikowanych do najwyższej oceny wynika z zaawansowanego stopnia rekultywacji zwałowisk Zagłębia Ruhry. W przypadku dostępności najniższą rangę otrzymały 4 zwałowiska, 3 - średnią, a pozostałe obiekty - dobrą, co wiąże się z licznymi formami zagospodarowania badanych obiektów.

Próba waloryzacji zwałowisk po górnictwie węgla kamiennego, zlokalizowanych w Zagłębiu Ruhry, przy wykorzystaniu zasad waloryzacji stworzonych dla zwałowisk w GZW, wykazała, iż konieczne były pewne modyfikacje tych zasad. Dotyczyły one głównie zagospodarowania i położenia zarówno samych zwałowisk, jak i ogólnego zagospodarowania terenu (m.in. turystycznego).

Analizując wyniki waloryzacji, daje się zauważyć istotność efektywnej rekultywacji zwałowisk, wynikającej ze szczegółowych uregulowań prawnych. Nie bez znaczenia jest również fakt, iż antropogeniczne formy terenu, takie jak zwałowiska pogórnicze, są wykorzystywane do celów dydaktycznych, rekreacyjnych czy krajobrazowych.

Kolejnym krokiem jest porównanie wyników waloryzacji dla obu grup zwałowisk, co pozwoli wskazać działania dotyczące rekultywacji i zagospodarowania zwałowisk zlokalizowanych na obszarze GZW, oparte na doświadczeniu niemieckim.

Wnioski:

- zwałowiska pogórnicze są obiektami o dużym potencjale dla rozwoju geoturystyki i turystyki kwalifikowanej;

- realizacja efektownych form zagospodarowania zwałowisk wiąże się z wcześniejszym zapewnieniem likwidacji ich negatywnego wpływu na środowisko oraz umiejętnie prowadzonej rekultywacji technicznej i biologicznej;

- ciągłość finansowania oraz efektywne zarządzanie zwałowiskami pogórniczymi zapewniają możliwości realizacji form zagospodarowania i funkcjonowania tych obiektów jako geoturystycznych;

- odpowiednie szczegółowe uregulowania prawne umożliwiają prowadzenie efektywnej rekultywacji oraz zagospodarowania zwałowisk pogórniczych;

- istnieje możliwość i potrzeba wykorzystania doświadczeń niemieckich w procesie zarządzania terenami zwałowisk pogórniczych na obszarze Górnośląskiego Zagłębia Węglowego.

\section{Literatura}

Gawor, Ł. (2004). Wybrane zagadnienia sozologii górniczej w Zagłębiu Ruhry i Górnośląskim Zagłębiu Węglowym (GZW) na przykładzie zwałowisk pogórniczych - studium porównawcze. Zeszyty Naukowe Politechniki Ślaskiej, Górnictwo, 260, 97-108. 
Gawor, Ł., Main, M. (2007). Ausgewählte Umweltprobleme im Ruhrgebiet und im Oberschlesischen Kohlenbezirk (GZW) am Beispiel von Bergehalden. In: Veröffentlichungen von der 16. Tagung für Ingenieurgeologie und vom Forum Junge Ingenieurgeologen, Bochum, 07. bis 10. März 2007, Hsg. Otto F., 95-103.

Gawor, Ł., Szmatłoch, A. (2010). Koncepcja waloryzacji zwałowisk po górnictwie węgla kamiennego na przykładzie Górnośląskiego Zagłębia Węglowego. Acta Geographica Silesiana, 7, 23-30.

Held, T., Schmitt, T. (2001). Vom Spitzkegel zur Landmarke. Geographische Rundschau, H.9, Band $53,19-26$.

Labus, K. (2005). Parametryczna metoda oceny oddziaływania form turystyki na obiekty przyrody nieożywionej. Zeszyty Naukowe Politechniki Śląskiej, Górnictwo, 269.

Schulz, D. (2004). Recultivation of Mining Waste Dumps in the Ruhr Area, Germany. W: Water, Air \& Soil Pollution, Springer Netherlands, 89-98.

Wiggering, H., Kerth, M., (1991). Bergehalden des Steinkohlenbergbaus. Braunschweig/Wiesbaden: Verlag Friedr. Vieweg \& Sohn Verlagsgesellschaft mbH.

Lukasz Gawor, dr, Politechnika Śląska, Instytut Geologii Stosowanej.

Zainteresowania naukowe: sozologia górnicza, przepisy prawne dotyczące rekultywacji, rekultywacja i zagospodarowanie zwałowisk pogórniczych, geoturystyka.

Lukasz Gawor, PhD Łukasz Gawor, Silesian University of Technology, Institute of Applied Geology Scientific interests: mining sozology, legal regulations regarding reclamation, reclamation and using of post mining dumping grounds, geotourism.

Anna Szmatłoch, mgr inż., Politechnika Śląska, Instytut Geologii Stosowanej.

Zainteresowania naukowe: geoturystyka, waloryzacja obiektów przyrody nieożywionej, ochrona zabytków techniki, speleologia.

Anna Szmatloch, MSc Anna Szmatłoch, PhD student, Silesian University of Technology, Institute of Applied Geology.

Scientific interests: geotourism, valorization of non-animate nature objects, preservation of technical monuments, speleology.

Piotr Dolnicki, dr, Uniwersytet Pedagogiczny w Krakowie, Instytut Geografii, Zakład Turystyki i Badań Regionalnych.

Zainteresowania naukowe: geomorfologia, badania polarne, turystyka w obszarach polarnych.

Piotr Dolnicki, PhD Piotr Dolnicki, Pedagogical University in Cracow, Institute of Geography, Department of Tourism and Regional Studies.

Scientific interests: geomorphology, polar research, tourism in polar regions.

adres/address: Politechnika Śląska

Instytut Geologii Stosowanej, ul. Akademicka 2a, 44-100 Gliwice, Polska

(Łukasz Gawor, Anna Szmatłoch)

Uniwersytet Pedagogiczny w Krakowie

Instytut Geografii, Zakład Turystyki i Badań Regionalnych

ul. Podchorążych 2, 30-084 Kraków, Polska (Piotr Dolnicki)

e-mail: lukasz.gawor@polsl.pl (Lukasz Gawor)

anna.szmatloch@polsl.pl (Anna Szmatłoch)

pdolnick@up.krakow.pl (Piotr Dolnicki) 